\title{
Peroxisome proliferator-activated receptor gamma is induced during differentiation of colon epithelium cells
}

\author{
A-M Lefebvre', B Paulweber ${ }^{2}$, L Fajas ${ }^{1}$, J Woods $^{3}$, C McCrary ${ }^{3}$, \\ J-F Colombel ${ }^{4}$, J Najib ${ }^{1}$, J-C Fruchart ${ }^{1}$, C Datz ${ }^{2}$, H Vidal ${ }^{5}$, \\ P Desreumaux $^{4}$ and J Auwerx ${ }^{1}$ \\ ${ }^{1}$ U325 INSERM, Département d'Athérosclerose, Institut Pasteur, 1 rue Calmette, 59019, Lille, France \\ ${ }^{2}$ First Department of Internal Medicine, General Hospital of Salzburg, 5020 Salzburg, Austria \\ ${ }^{3}$ Merck Research Laboratories, Rahway, New Jersey 07065-0900, USA \\ ${ }^{4}$ Clinique des Maladies de I'Appareil Digestif, Hopital Claude Huriez, CRI 440048 CHU, 59037 Lille, France \\ ${ }^{5}$ U449 INSERM, Faculté de Médecine René Laennec, Université Claude Bernard, 69373 Lyon, France \\ (Requests for offprints should be addressed to J Auwerx)
}

\begin{abstract}
Peroxisome proliferator-activated receptor $\gamma(\operatorname{PPAR} \gamma)$, a fatty acid-activated nuclear receptor, is implicated in adipocyte differentiation and insulin sensitisation. In view of the association of dietary fat intake and bowel disease, the expression of PPAR $\gamma$ in rodent and human intestine was studied. Expression of PPAR $\gamma$ mRNA was examined by Northern blot hybridisation, RNase protection, and/or competitive RT-PCR assays, whereas PPAR $\gamma$ protein levels were evaluated by immunoblotting and immunohistochemistry. PPAR $\gamma$ mRNA and protein were abundantly expressed in colon relative to the small intestine both in rodents and in man. Interestingly, expression of
\end{abstract}

$\operatorname{PPAR} \gamma$ was primarily localised in the more differentiated epithelial cells in the colon. The level of expression of PPAR $\gamma$ in colon was similar to the levels seen in adipose tissue. Expression of PPAR $\gamma$ increased from proximal to distal segments of the colon in man. In Caco-2 and HT-29 human adenocarcinoma cells, PPAR $\gamma$ expression increased upon differentiation, consistent with PPAR $\gamma$ being associated with a differentiated epithelial phenotype. High-level expression of PPAR $\gamma$ was observed in the colon, but not in the small intestine, suggesting a potential role of this nuclear receptor in the colon.

Journal of Endocrinology (1999) 162, 331-340

\section{Introduction}

Bowel diseases, including inflammatory and neoplastic bowel disease, are prevalent disorders in Western populations. In fact, colorectal cancer is the second leading cause of death from cancer (Wingo et al. 1995). A remarkable difference in incidence worldwide has led to the attractive hypothesis of an association between dietary fat intake and the incidence of colorectal cancer (Potter \& McMichael 1986, De Vries \& Van Noorden 1992, Potter 1992). Moreover, recent data demonstrated effects of dietary fat content on intestinal polyp formation and survival in a mouse model of multiple intestinal neoplasia (Wasan et al. 1997). Non-steroidal anti-inflammatory drugs, such as aspirin or indomethacin, have been shown to reduce the frequency of colorectal cancer (Thun et al. 1991, Giovanucci et al. 1995), an effect linked to their ability to inhibit cyclooxygenase activity and to block the production of arachidonic acid-derived prostaglandins. Inflammatory bowel disease also seems to be associated with perturbations in lipid metabolism. In fact, increased levels of prostaglandin $\mathrm{E}_{2}$ and leukotriene $\mathrm{B}_{4}$ are found in intestinal mucosa from patients with inflammatory bowel disease and have been suggested to play an important role in its pathogenesis (Sharon \& Stenson 1984, Lauritsen et al. 1986). Furthermore, changing the quality of dietary fat has been shown to beneficially influence inflammatory bowel disorders (Lee \& Austen 1985, Stenson et al. 1992, Belluzi et al. 1996).

The link between perturbations in fatty acid and arachidonic acid metabolism with both colorectal cancer and inflammatory bowel disease led us to investigate the expression of the fatty acid-activated transcription factor, peroxisome proliferator-activated receptor $\gamma(\operatorname{PPAR} \gamma)$ in the intestine. PPAR $\gamma$, a nuclear hormone receptor, has been shown to trigger adipocyte differentiation (Tontonoz et al. 1994) and improve insulin sensitivity (reviewed in Spiegelman \& Flier 1996, Schoonjans et al. 1997). A metabolite of arachidonic acid, 15-deoxy- $\Delta^{12,14}$ prostaglandin $\mathrm{J}_{2}$, has been identified as a natural ligand of $\operatorname{PPAR} \gamma$, whereas anti-diabetic thiazolidinediones are synthetic ligands (Forman et al. 1995, Kliewer et al. 1995). 
Fatty acids and prostaglandins, present in the lumen of the colon or provided to the intestinal cells through the circulation, could be potential activators for PPAR $\gamma$ (Göttlicher et al. 1993). In this study, we investigated the expression of PPAR $\gamma$ in the intestinal tract of rodents and humans. PPAR $\gamma$ was highly expressed in the colon at levels similar to those found in adipose tissue. These in vivo observations were corroborated by in vitro studies, which demonstrated high-level expression of $\operatorname{PPAR} \gamma$ in the human colon cell line, Caco-2. Interestingly, PPAR $\gamma$ levels increased in this cell line with differentiation.

\section{Materials and Methods}

Tissues samples

Human ileum and colon biopsies were obtained from untreated patients ( $n=4$; females, mean age $57 \pm 10$ years) having had a colonoscopy for irritable bowel disease as part of their diagnostic evaluation. Moreover, six endoscopic biopsies per patient were taken systematically from macroscopically normal mucosa at different locations of the colon between caecum and rectum. Mesenteric and subcutaneous white adipose tissues were obtained from patients undergoing elective gallbladder surgery $(n=3$; females, mean age $49 \pm 7$ ). These biopsies were immediately frozen and later used to evaluate expression of PPAR $\gamma$ mRNA by competitive PCR, and PPAR $\gamma$ protein by immunoblot analysis. Subjects gave informed consent and the protocol of the study was approved by the ethics committees of the University Hospital in Lille and the Landeskranken Anstalt of Salzburg. Duodenal, ileal and different parts of colon were systematically obtained from C57BL6/J mice (IFFA-Credo, Arbresle, France). Different parts of colon and epididymal adipose tissues were also obtained from 7-week-old normal SpragueDawley rats (IFFA-Credo). Biopsies of the animals were processed for Northern blot, immunoblot, and immunohistochemical analysis.

\section{Cell culture}

The human colon adenocarcinoma cell lines Caco-2 and HT-29 were obtained from ATCC, Rockville, MD, USA. Caco-2 cells were grown in Dulbecco's modified Eagle medium containing 15\% fetal calf serum (v/v), $50 \mu \mathrm{g} / \mathrm{ml}$ streptomycin, $50 \mu \mathrm{g} / \mathrm{ml}$ penicillin and $0 \cdot 1 \mathrm{mM}$ non-essential amino acids. The cells were subcultured when they were $80 \%$ confluent by using $0.5 \%$ trypsin and seeded at a density of $5 \times 10^{4} \mathrm{cells} / \mathrm{cm}^{2}$. Differentiation of the Caco-2 cells into enterocytes can be spontaneously obtained in the absence of any inducers by maintaining them at confluence for approximately 20 days (Pinto et al. 1983). HT-29 cells were grown in McCoy's medium supplemented with $10 \%$ fetal calf serum (v/v), $50 \mu \mathrm{g} / \mathrm{ml}$

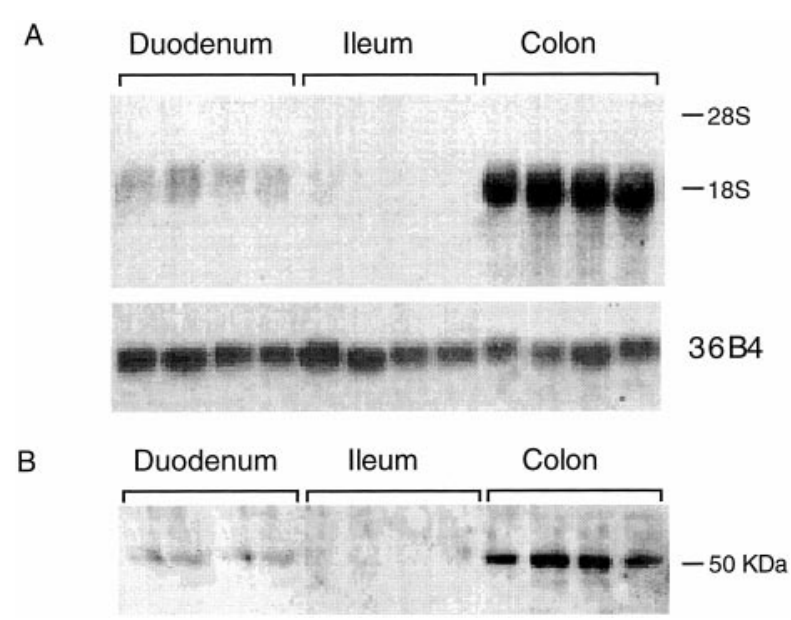

Figure 1 Northern and Western blot analysis of PPAR $\gamma$ expression in C57BL6/J mouse intestine. (A) Total RNA was extracted from total duodenum, ileum and colon of C57BL6/J mice $(n=4)$ and PPAR $\gamma$ and 36B4 mRNA levels were measured as described in Materials and Methods. (B) Proteins from total duodenum, ileum, and colon of C57BL6/J mice $(n=4)$ were separated on $10 \%$ SDS-PAGE and blotted onto nitrocellulose filters. Immunodetection of PPAR $\gamma$ protein was performed with a rabbit anti-PPAR $\gamma$ antibody and visualised with the ECL system.

streptomycin, and $50 \mu \mathrm{g} / \mathrm{ml}$ penicillin. After confluency, HT-29 cells growing in the absence of glucose exhibit an enterocytic differentiation (Zweibaum et al. 1985).

\section{$R N A$ analysis by Northern blot, competitive reverse transcription (RT)-PCR and RNase protection assay}

RNA was isolated by the acid guanidinium thiocyanate/ phenol/chloroform method (Chomczynski \& Sacchi 1987). Northern blot hybridisation with a random primedlabelled cgPPAR $\gamma$ probe (Aperlo et al. 1995) and 36B4 (encoding the human acidic ribosomal phosphoprotein, PO) as a control probe (Masiakowski et al. 1982), was performed exactly as described (Saladin et al. 1995). In human tissue samples, the absolute mRNA concentration of PPAR $\gamma$ was measured from $0 \cdot 1 \mu \mathrm{g}$ of total RNA by reverse transcription (RT) reaction followed by competitive PCR (RT-competitive PCR) exactly as described previously (Fajas et al. 1997). After 40 cycles of amplification, results were expressed as amol/ $\mu \mathrm{g}$ total RNA. The RNase protection experiments, using an anti-sense riboprobe containing the untranslated exons $\mathrm{A} 1$ and $\mathrm{A} 2$ of the human PPAR $\gamma$ gene, were performed as described previously (Fajas et al. 1998). Labelled synthetic anti-sense RNA probe $\left(5 \times 10^{5}\right.$ c.p.m. $)$ was hybridised with $10 \mu \mathrm{g}$ of different RNA samples in a total volume of $25 \mu \mathrm{l}$ for $16 \mathrm{~h}$ at $30{ }^{\circ} \mathrm{C}$. Samples were incubated for $1.5 \mathrm{~h}$ at the same temperature with a mixture of RNase T1 $(2 \mathrm{mg} / \mathrm{ml}$, Boehringer Mannheim, Meylan, France) and RNase A (40 mg/ml, Sigma, St Louis, MO, USA). Nucleases were 


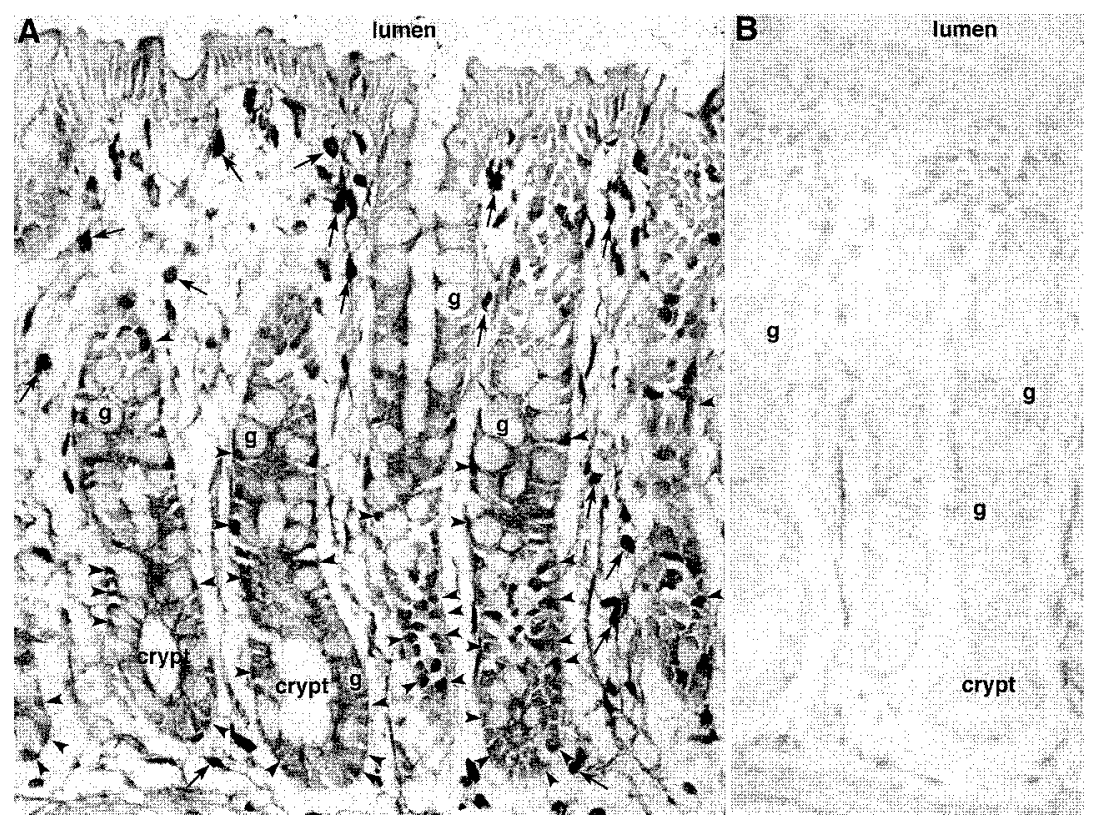

Figure 2 Immunolocalisation of PPAR $\gamma$ in normal rat colon. (A) Immunohistochemical analysis of PPAR $\gamma$ in rat cryosections. Note the reaction product seen within the nuclei of the epithelial cells (arrowheads) and in the monocytic cells of the lamina propria (arrows). (B) Control rat section in which the primary antibody was incubated with the section in the presence of competing free peptide of the same sequence as that used to immunise the original rabbit. In this example the specific labelling is entirely eliminated and only a faint outline of the tissue is visible. Original magnification $\times 630$.

then inactivated by adding a mixture of $20 \%$ SDS and $20 \mathrm{mg} / \mathrm{ml}$ proteinase $\mathrm{K}$ during $15 \mathrm{~min}$ at $37^{\circ} \mathrm{C}$ followed by phenol/chloroform extraction. After precipitation with ethanol, the samples were resuspended in $5 \mu$ formamide loading buffer and resolved on a denaturing $6 \%$ polyacrylamide/urea sequencing gel, which was dried after the electrophoresis and exposed to X-ray film.

\section{SDS-PAGE and immunoblotting analysis}

Cells were homogenised in a cell lysis buffer consisting of PBS with $1 \%$ Triton X-100 (Sigma) to which a freshly prepared protease inhibitor cocktail was added consisting of $40 \mu \mathrm{g} / \mathrm{ml} \mathrm{4-(2-aminoethyl)-benzene} \mathrm{sulfonylfluoride}$ (AEBSF), $5 \mathrm{mg} / \mathrm{ml}$ EDTA-Na $2,1 \mu \mathrm{g} / \mathrm{ml}$ leupeptin, $1 \mu \mathrm{g} / \mathrm{ml}$ pepstatin (ICN, Orsay, France). Tissues were homogenised with a polytron in extraction buffer consisting of PBS with $1 \%$ NP-40, $0.5 \%$ sodium deoxycholate, $0 \cdot 1 \%$ SDS (Sigma) and the fresh protease inhibitor cocktail described above. Protein extracts were obtained after centrifugation of the lysate at $13000 \mathrm{~g}$ at $4{ }^{\circ} \mathrm{C}$ and protein concentrations were determined at $595 \mathrm{~nm}$ with the Biorad protein colorimetric assay system (Biorad, Ivry-surSeine, France). Ten microgams of each total protein lysate were separated on a $12 \%$ polyacrylamide gel according to Laemmli (1970), and proteins were transferred to nitrocellulose filters as described by Towbin et al. (1979). The membrane was blocked for $2 \mathrm{~h}$ at $21{ }^{\circ} \mathrm{C}$ in blocking buffer (20 mM Tris, $100 \mathrm{mM} \mathrm{NaCl,} \mathrm{1 \%} \mathrm{Tween-20,} \mathrm{5 \%}$ skimmed milk). Next, the filter was incubated overnight at $4{ }^{\circ} \mathrm{C}$ with a $1: 500$ dilution of rabbit $\operatorname{IgG}$ anti-human PPAR $\gamma(0.5 \mathrm{mg} / \mathrm{ml})$, developed against an N-terminal human PPAR $\gamma$ peptide (amino acids 20-104). The secondary antibody, a horseradish peroxidase (HRP)conjugated goat anti-rabbit IgG (Pasteur Diagnostic Sanofi, Marnes la Coquette, France) diluted at 1:5000, was incubated with the filter for $1 \mathrm{~h}$ at $21{ }^{\circ} \mathrm{C}$. The detection of the reaction was done by enhanced chemiluminescence (ECL) according to the manufacturer's protocol (Amersham, Les Ulis, France).

\section{Immunohistochemistry and immunocytochemistry}

Colon tissue from normal Sprague-Dawley rats was prepared as follows. The vasculature of a deeply anaesthetised animal was cleared by perfusion with PBS followed by periodate-lysine-paraformaldehyde (PLP) fixative (McLean \& Nakane 1974). The colon was removed, a section from the middle third was harvested and fixed a further $6 \mathrm{~h}$ at $4{ }^{\circ} \mathrm{C}$ in fresh PLP fixative. The fixed tissue was then cryoprotected by incubation for $4 \mathrm{~h}$ in $10 \%$ sucrose $/ 0 \cdot 1 \mathrm{M}$ phosphate buffer $\mathrm{pH} 7 \cdot 3$ and frozen in OTC media in cryomoulds prior to storage at $-70{ }^{\circ} \mathrm{C}$. Cryosections $(6 \mu \mathrm{m})$ were cut on a Reichert-Jung 

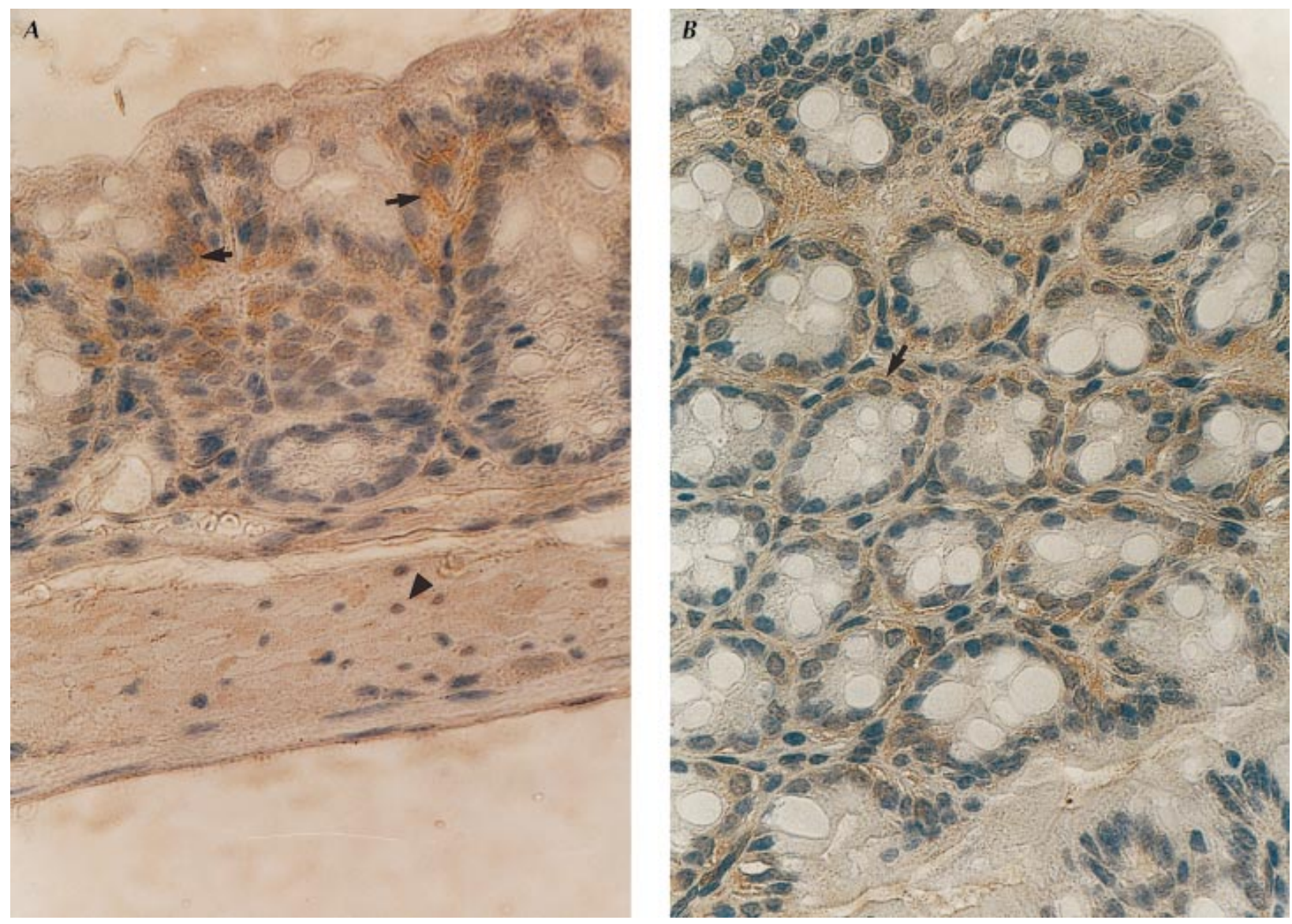

Figure 3 Immunolocalisation of PPAR $\gamma$ in normal mouse colon. (A and B) Immunohistochemical analysis of PPAR $\gamma$ in paraffin sections of mouse colon. Note the intense brown coloration in nucleus and cytoplasm of the epithelial cells (arrows) and in smooth muscle cells (arrowhead). Nuclei were counterstained with haematoxylin. Original magnification $\times 630$.

Cryocut 1800 cryostat. Immunohistochemical labelling was performed using the Vector ABC labelling protocol as follows (Vector Laboratories Inc., Burlingame, CA, USA). Sections were pre-treated with $3 \%$ hydrogen peroxide in methanol for 20 min to inactivate endogenous peroxidases, followed by permeabilisation in $0 \cdot 1 \%$ Triton $\mathrm{X}-100$ in PBS at $4{ }^{\circ} \mathrm{C}$ for $5 \mathrm{~min}$. Putative biotin and avidin binding sites within the sections were blocked with biotin and avidin solutions as specified in the Vector blocking kit. To further reduce the possibility of non-specific antibody binding, the sections were then incubated with 1.5\% normal donkey serum followed by incubation with a solution containing $5 \%$ non-fat dry milk and $0 \cdot 1 \%$ BSA. Specific labelling was then carried out by incubation with $5 \mu \mathrm{g} / \mathrm{ml} \mathrm{IgG} \mathrm{isolated} \mathrm{from} \mathrm{a} \mathrm{rabbit} \mathrm{immunised} \mathrm{with} \mathrm{an} 18$ amino acid fragment of PPAR $\gamma$ (amino acids 116-134; J Auwerx, unpublished observations). In order to demonstrate specificity, sequential sections were incubated with immune $\operatorname{IgG}$ in the presence of $20 \mu \mathrm{g} / \mathrm{ml}$ of immunising peptide or in the presence of non-immune $\operatorname{IgG}$. Bound antibodies were visualised by incubation first with biotinylated donkey $\mathrm{F}\left(\mathrm{ab}^{\prime}\right)_{2}$ anti-rabbit $\operatorname{IgG}$, followed by incubation with avidin-biotin-HRP complexes prepared from the Vector Elite immunoperoxidase kit. Peroxidase reaction product was developed using the glucose oxidase/ diaminobenzidine (DAB)/nickel method (Shu \& Fan 1988). Digital micrographs were taken using a Kodak Megaplex camera mounted on a Zeiss Axiophot microscope using a $\times 40$ objective.

Mouse colon tissues were fixed in 4\% paraformaldehyde acid (PFA) at $4{ }^{\circ} \mathrm{C}$ overnight, dehydrated in alcohol and embedded in paraffin. Five-micron sections were then deparaffined with xylene and rehydrated by ethanol treatment. Caco- 2 cells were fixed in 3\% PFA $/ 2 \%$ sucrose for $15 \mathrm{~min}$ at $21{ }^{\circ} \mathrm{C}$ and permeabilised in cold methanol/ acetone $(\mathrm{v} / \mathrm{v})$ for $5 \mathrm{~min}$ at $21^{\circ} \mathrm{C}$. Immunochemistry was performed with the peroxidase-anti-peroxidase universal DAKO Stain Kit according to the manufacturer's protocol (DAKO, Copenhagen, Denmark) and using a rabbit IgG anti-human PPAR $\gamma$ (Fajas et al. 1997) diluted 1:50. Negative controls were incubated with preimmune serum. 
A

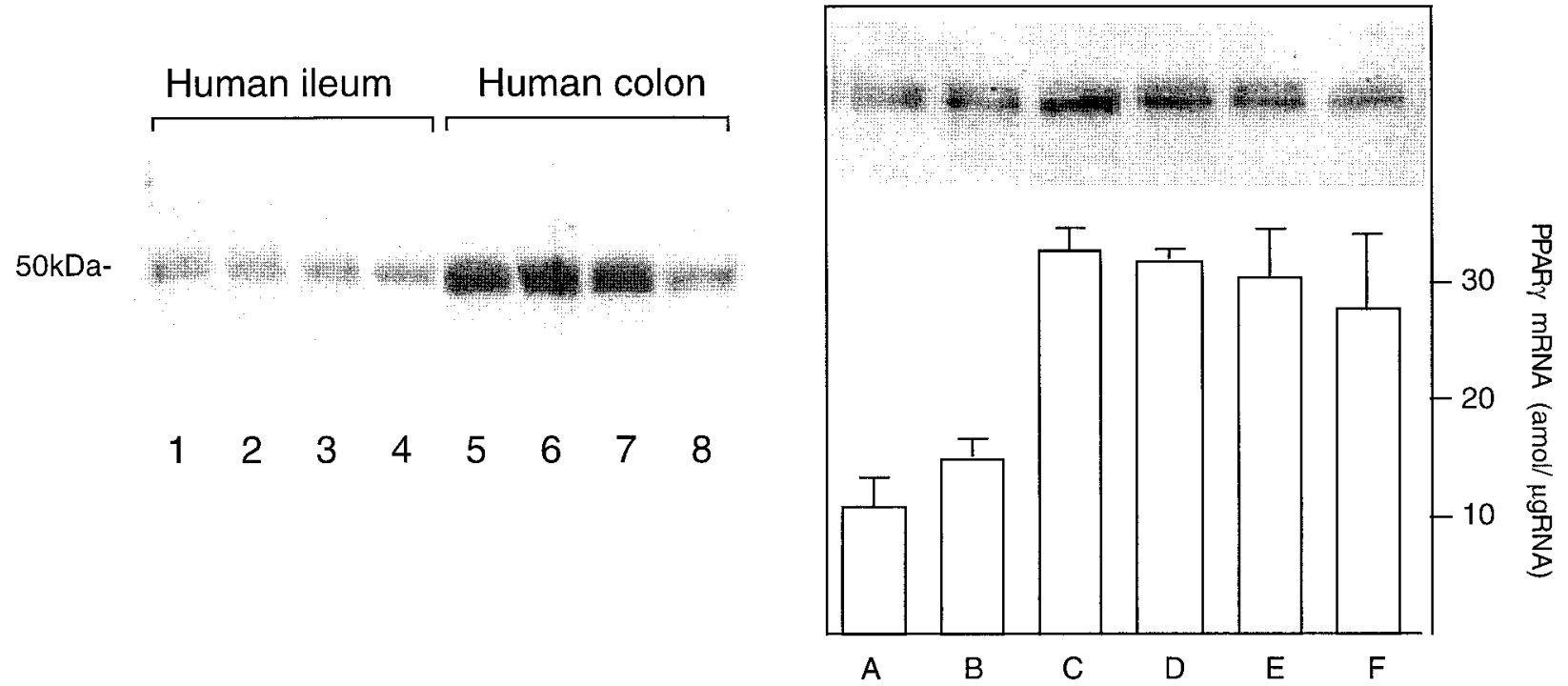

B Caecum $\longrightarrow$ Rectum

Figure 4 Expression of PPAR $\gamma$ mRNA and protein in the human ileum and colon. (A) Proteins from total ileum $(n=4)$ and colon $(n=4)$ from different human biopsies were separated on 10\% SDS-PAGE and blotted onto nitrocellulose filters. Immunodetection of PPAR $\gamma$ protein was performed with a rabbit anti-PPAR $\gamma$ antibody and visualised with the ECL system. (B) Quantification of PPAR $\gamma$ mRNA by competitive RT-PCR in six different areas of human colon in biopsies obtained from the same control subjects $(n=4)$. The biopsies were taken in distinct regions of the colon between caecum and rectum. Amount of PPAR $\gamma$ mRNA is expressed in amol/ $\mu \mathrm{g}$ total RNA. The inset shows a Western blot of corresponding protein extracts from colon biopsies obtained from distinct regions of the human colon between caecum to rectum. Proteins were separated by SDS-PAGE and transferred onto nitrocellulose filters (inset). The immunodetection was obtained with rabbit anti-PPAR $\gamma$ antibodies and visualised with ECL.

\section{Results}

Expression and immunohistochemical localisation of PPAR in rodent intestine

To study the expression of PPAR $\gamma$ in mouse intestine, we analysed the presence of the mRNA in various parts of the mouse gastrointestinal tract by Northern blot. A single $1.8 \mathrm{~kb}$ mRNA species corresponding to PPAR $\gamma$ mRNA was present in the entire intestine, but the colon showed at least a 10-fold higher expression level relative to other parts of the intestine (Fig. 1A). Next, we asked whether the PPAR $\gamma$ mRNA expression correlated with PPAR $\gamma$ protein expression across the gastrointestinal tract. Therefore, a rabbit anti-PPAR $\gamma$ polyclonal antibody (Fajas et al. 1997) was used in a Western blot experiment to analyse PPAR $\gamma$ protein expression in the same intestinal fragments as used for RNA extraction (Fig. 1B). Immunoblotting experiments showed the presence of a $50 \mathrm{kDa}$ band corresponding to PPAR $\gamma$ only in the colon. To localise $\operatorname{PPAR} \gamma$ expression in the colon, immunohistochemistry was performed on serial cryosections of the rat colon. $\operatorname{PPAR} \gamma$ was expressed in epithelial cells facing the colonic lumen (Fig. 2A). Immunolocalisation of PPAR $\gamma$ in normal rat colon seen within the nuclei of the epithelial cells (arrowheads, Fig. 2A) and in the monocytic cells of the lamina propria (arrows, Fig. 2A). In the control section the specific labelling was entirely eliminated and only a faint outline of the tissue was visible (Fig. 2B). Lower levels of $\operatorname{PPAR} \gamma$ were observed in the muscularis mucosae, submucosal and muscular layers (data not shown). PPAR $\gamma$ expression was also studied in paraffin sections of normal mouse colon (Fig. 3A and B). Similar to in the rat, PPAR $\gamma$ was abundantly expressed in epithelial cells (arrows) and to a lower level in the muscular layer of the mouse colon (arrowhead). The expression of PPAR $\gamma$ could be observed in both the nucleus and cytoplasm of epithelial cells.

\section{Quantification of PPAR $m R N A$ and protein in human colon}

To verify whether PPAR $\gamma$ was also present in the human gastrointestinal tract, ileum and colon biopsies were collected from four normal subjects. PPAR $\gamma$ protein expression was analysed in human ileum and colon by Western blotting. Similar to findings in rodents, PPAR $\gamma$ expression was more pronounced in colon (Fig. 4A, lanes 5-8) in comparison with ileum (lanes 1-4). Multiple biopsies were taken at different locations throughout the colon. Total RNA was extracted and used to quantify PPAR $\gamma$ mRNA by competitive RT-PCR. High-level expression of $\operatorname{PPAR} \gamma$ was demonstrated in the entire colon, but the expression was consistently higher in the distal colon (up 


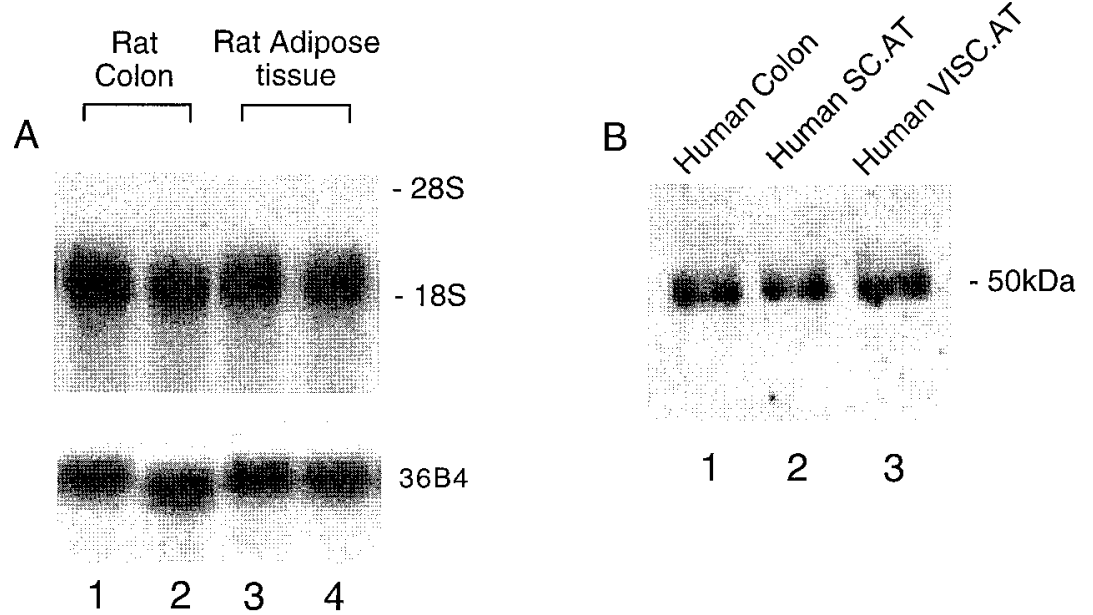

Figure 5 Comparative expression of PPAR $\gamma$ in rat and human colon and adipose tissue. (A) Total RNA was extracted from colon (lanes 1 and 2) and epididymal adipose tissue (lanes 3 and 4) of Sprague-Dawley rats and PPAR $\gamma$ and 36B4 (loading control) mRNA levels were measured as described in Materials and Methods. (B) Proteins from human colon (lane 1), subcutaneous (SC. AT) (lane 2) and mesenteric (VISC. AT) (lane 3) adipose tissue biopsies were separated on 10\% SDS-PAGE and blotted onto a nitrocellulose filter. Immunodetection of PPAR $\gamma$ protein was performed with a rabbit anti-PPAR $\gamma$ antibody and visualised with the ECL system.

to $30 \mathrm{amol} / \mu \mathrm{g}$ total RNA) relative to the proximal colon and caecum $(10 \mathrm{amol} / \mu \mathrm{g}$ total RNA) (Fig. 4B). In addition, proteins were extracted from the same biopsies for immunodetection of PPAR $\gamma$ by Western blotting. $\operatorname{PPAR} \gamma$ protein is present throughout the entire colon, from caecum to rectum, but its expression appears somewhat less pronounced in the caecum (Fig. 4B, inset).

Comparison of PPAR $\gamma$ expression in colon and adipose tissue in rat and human

The relative levels of PPAR $\gamma$ mRNA and protein expression were then analysed in adipose tissue and colon. We compared the level of expression of PPAR $\gamma$ mRNA in colon and adipose tissue of normal rats by Northern blot hybridisation (Fig. 5A). Expression in rat colon epithelium (lanes 1 and 2) was at the same level as the expression of PPAR $\gamma$ mRNA in rat epididymal adipose tissue (lanes 3 and 4). To extend these results to humans, PPAR $\gamma$ protein expression was analysed by immunoblotting in human colon and adipose tissue (Fig. 5B). PPAR $\gamma$ protein was present at comparable levels in human colon (lane 1), human subcutaneous (lane 2) and human mesenteric adipose tissue (lane 3).

Expression and cytolocalisation of PPAR in human colon adenocarcinoma cells

In order to establish an in vitro model for the study of the role of PPAR $\gamma$ in colonic function and metabolism, we investigated the expression of PPAR $\gamma$ in the human Caco-2 cell line, which was derived from an adenocarcinoma of human colon. This cell line was shown to be an appropriate model of enterocytic differentiation, since it can undergo spontaneous differentiation when maintained confluent for extended periods (Pinto et al. 1983). Caco-2 cells were differentiated during 20 days. Total RNA was isolated at different times of the differentiation process (Fig. 6A, lanes 2-7) and was analysed by RNase protection assay, using an anti-sense riboprobe containing the untranslated exons A1 and A2 of the human PPAR $\gamma$ gene, allowing us to measure the mRNA expression level of PPAR $\gamma 1$ and a newly described PPAR $\gamma$ isoform, PPAR $\gamma 3$ (Fig. 6A) (Fajas et al. 1998). Both PPAR $\gamma 1$ and $\gamma 3$ give rise to an identical PPAR $\gamma 1$ protein product (Fajas et al. 1998). Whereas a slight induction of the PPAR $\gamma 1$ mRNA levels could be observed, PPAR $\gamma 3$ mRNA was induced approximately $2 \cdot 5$-fold upon differentiation of the Caco-2 cells (Fig. 6B). Western blot analysis showed that $\operatorname{PPAR} \gamma$ was poorly expressed in undifferentiated cells (lanes 1-3) compared with differentiated Caco-2 cells (lanes 4-6), where PPAR $\gamma$ protein was expressed at a high level (Fig. 6C). Along the same lines, the differentiation of another human adenocarcinoma cell line, HT-29, is associated with an induction of $\operatorname{PPAR} \gamma$ protein level (Fig. 6C, lanes 4-6). This results suggests that the upregulation of $\operatorname{PPAR} \gamma$ protein expression is at least in part a consequence of the increased transcription of the PPAR $\gamma$ gene, although a post-transcriptional effect on mRNA stability cannot be excluded. Cytolocalisation of PPAR $\gamma$ 
A

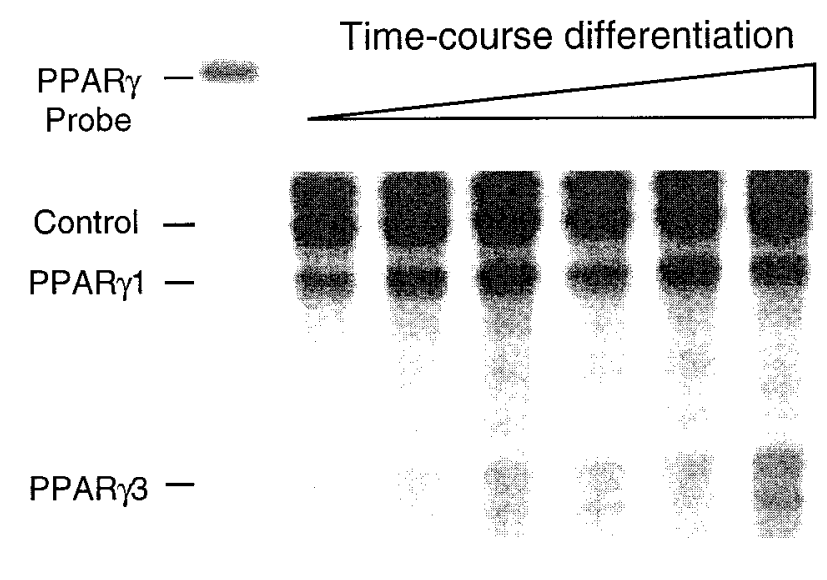

$\begin{array}{lllllll}1 & 2 & 3 & 4 & 5 & 6 & 7\end{array}$
C

\section{Undifferentiated Differentiated}

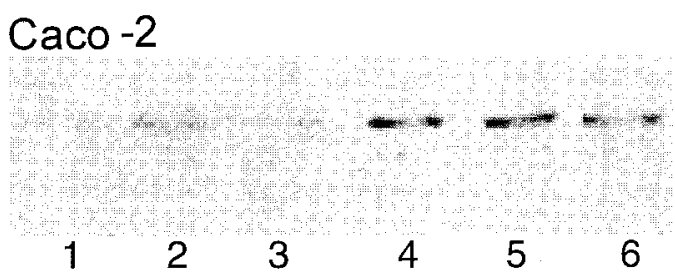

HT-29

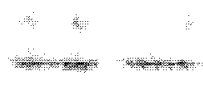

1

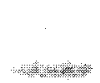

3

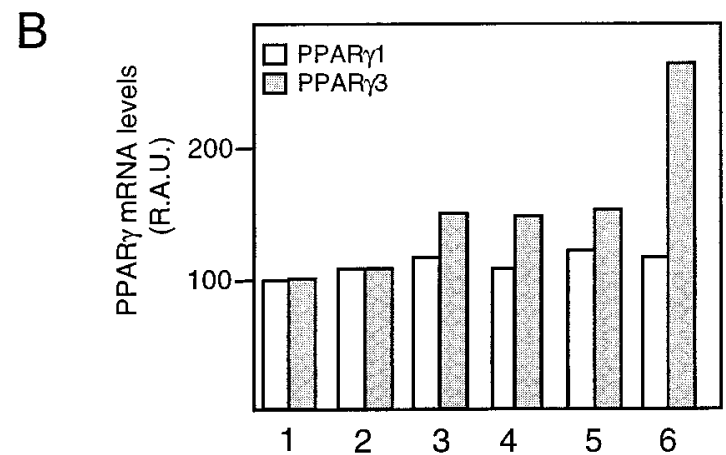

Figure 6 PPAR $\gamma$ expression in the human adenocarcinoma cell line Caco-2. (A) Total RNA from Caco-2 cells at different times of the differentiation process were analysed by RNase protection assay (lanes 2-7). The RNase protection experiments were done using an anti-sense riboprobe containing the untranslated exons A1 and A2 of the human PPAR $\gamma$ gene (lane 1: control probe). (B) The autoradiograph shown in panel (A) was scanned densitometrically and the RNA values were expressed in relative absorbance units (RAU) taking the undifferentiated control values as 100\%. (C) Proteins from Caco-2 and HT-29 cell lysates were separated by SDS-PAGE and transferred onto nitrocellulose filters. Immunodetection was performed with rabbit anti-PPAR $\gamma$ antibodies and visualised with the ECL system. The first three lanes (1-3) were loaded with $10 \mu \mathrm{g}$ protein obtained from the non-differentiated Caco-2 or HT-29 cells, the last three lanes (4-6) were loaded with $10 \mu \mathrm{g}$ protein from differentiated-Caco-2 or HT-29 cells.

was performed both in undifferentiated and in differentiated Caco-2 cells (Fig. 7). PPAR $\gamma$ protein seems highly enriched in the differentiated cell nucleus. The special morphology of the differentiated cells, with numerous tightly packed cells in which the cytoplasm is not easily distinguishable and which have a tendency to pile up in domes, does not allow, however, a clear demonstration of whether PPAR $\gamma$ protein is also present in the cytoplasm.

\section{Discussion}

PPARs are fatty acid-activated transcription factors belonging to the nuclear receptor superfamily. $\operatorname{PPAR} \gamma$, a subtype of the PPAR family, is predominantly expressed in adipose tissue, where it controls critical steps of lipid homeostasis and functions as a key trigger of adipocyte differentiation (reviewed in Auwerx et al. 1996). Two others subtypes of PPAR, PPAR $\alpha$ and $\delta$ have been identified. PPAR $\alpha$, the predominant subtype expressed in liver, plays an important role in hepatic fatty acid $\beta$-oxidation and its expression has been detected in rodent small intestine (Mansen et al. 1996). Also, PPAR $\gamma$ was reported to be expressed in the gastrointestinal tract in rodents (Braissant et al. 1995). From these studies it is unclear, however, whether it is preferentially expressed in small intestine (Braissant et al. 1995) or colon (Mansen et al. 1996). We recently described the predominant 

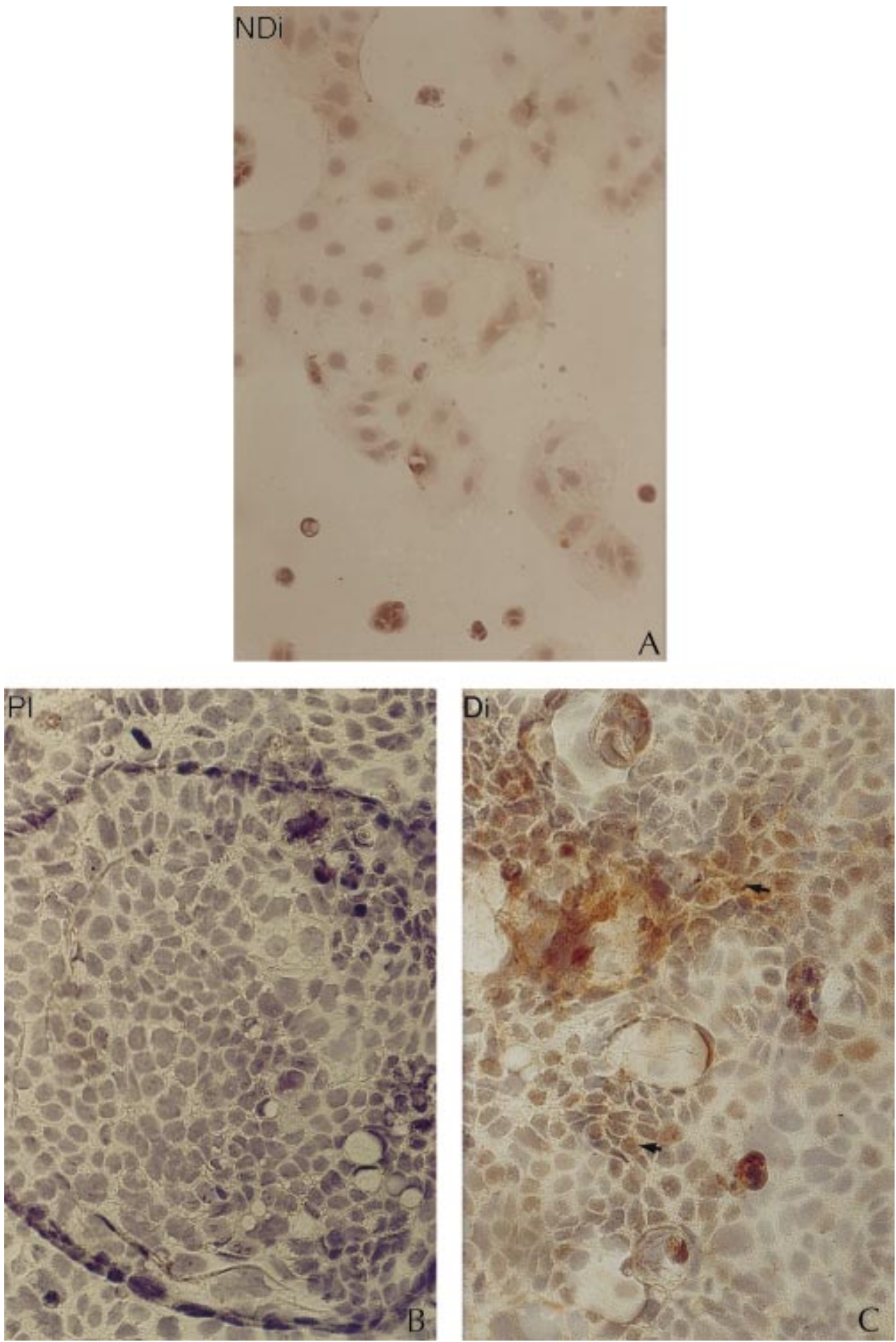

Figure 7 Immunocytochemical analysis of PPAR $\gamma$ expression in Caco-2 cells. Immunolabelling was performed in non-differentiated Caco-2 cells (A) (NDi; non-differentiated) and in differentiated Caco-2 cells ( $B$ and $C$ ). Negative controls were performed for differentiated Caco-2 cells by incubation with preimmune serum (B) (Pl; preimmune serum). Positive cells were visualised with brown DAB (C) (Di). Original magnification $\times 400$. 
expression of PPAR $\gamma$ in human colon by competitive RT-PCR (Auboeuf et al. 1997, Fajas et al. 1997). Although PPAR $\alpha$ and $\delta$ are also expressed in the human gastrointestinal tract, their level of expression is much lower than that of PPAR $\gamma$ (Auboeuf et al. 1997).

In this more detailed study on PPAR $\gamma$ expression, high levels of PPAR $\gamma$ mRNA and protein were detected in rodent and human colon. Both in rodents and in man, PPAR $\gamma$ protein is more expressed in colon relative to the other parts of the intestinal tract. The expression of PPAR $\gamma$ in human colon had a tendency to increase in the distal segments of the colon relative to the proximal colon. By immunohistochemistry of the mouse and rat colon, $\operatorname{PPAR} \gamma$ expression was confined to differentiated epithelial cells, monocytic cells, and some cells in the muscular layer. We also detected PPAR $\gamma$ in human adenocarcinoma colon cell lines Caco-2 and HT-29. Expression of PPAR $\gamma$ protein increased with differentiation of these cells, consistent with its expression in differentiated epithelial cells in rat and mouse colon. The results in the present study confirm and extend previous reports (Mansen et al. 1996, Auboeuf et al. 1997) showing a predominant expression of PPAR $\gamma$ in colon, with $\operatorname{PPAR} \alpha$ preferentially expressed in the small intestine. These observations, as well as our current results, are, however, not consistent with in situ hybridisation results reported by Braissant et al. (1995) who describe a decrease of PPAR $\gamma$ expression from jejunum to colon in the rat intestinal tract.

Our data show high levels of PPAR $\gamma$ expression in colon, comparable to the expression in the adipose tissue, which was previously considered to be the main site of PPAR $\gamma$ expression. Contamination of colon samples with adipose tissue cannot account for the high levels of PPAR $\gamma$ observed in the colon, since colon samples obtained in mice were carefully dissected and all fat was carefully removed. In addition, rehybridisation of the Northern blot with a leptin cDNA (Zhang et al. 1996) did not reveal any signal, excluding adipose tissue contamination (data not shown). Furthermore, human biopsies cannot be contaminated with visceral adipose tissue because only mucosa was harvested.

Several clinical reports have noted the importance of dietary fat content and fatty acid-derived products, such as prostaglandins, in relation to diseases of the colon (Lee \& Austen 1985, Potter \& McMichael 1986, De Vries \& Van Noorden 1992, Potter 1992, Stenson et al. 1992, Belluzi et al. 1996, Wasan et al. 1997). Recent studies have shown that the arachidonic acid metabolite 15 -deoxy- $\Delta^{12,14}$ $\mathrm{PGJ}_{2}$ is a natural ligand of PPAR $\gamma$ (Forman et al. 1995, Kliewer et al. 1995), suggesting that some effects of dietary fat in the colon might be mediated by changing the quantity or quality of fatty acids, which are precursors of PPAR $\gamma$ ligands. The relevance of dietary fat content to diseases of the colon, as well as the results of the present study, which demonstrates high-level expression of
$\operatorname{PPAR} \gamma$ in differentiated epithelial cells of the colon, warrants a careful evaluation of the involvement of PPAR $\gamma$ in colon pathology. The conservation of PPAR $\gamma$ expression in the colon in several species (man and rodents), as well as differentiation-dependent expression in Caco-2 and HT-29 cells, provides both in vivo and in vitro models for such further exploration.

\section{Acknowledgements}

The technical help of Caroline Bisiaux, Alain Pockyn, Paulette Vallier and Delphine Cayet is gratefully acknowledged. Discussions and support from Drs R Heyman, M Leibowitz and D Moller are acknowledged. Johan Auwerx is a research director with the Centre National de Recherche Scientifique (France). This work was supported by grants from INSERM (PROGRES no. 4PO2OD), Région Nord-Pas-de-Calais, Actions Intégrées Franco-Autrichiennes du Ministère des Affaires Etrangères (AMADEUS 1997), Fondation de France and ARC.

\section{References}

Aperlo C, Pognonec P, Saladin R, Auwerx J \& Boulukos K 1995 Isolation and characterisation of the hamster peroxisomal proliferator-activated receptor $\operatorname{hPPAR} \gamma$, a member of the nuclear hormone receptor superfamily. Gene 162 297-302.

Auboeuf D, Rieusset J, Fajas L, Vallier P, Frering V, Riou JP, Laville M, Staels B, Auwerx J \& Vidal H 1997 Tissue distribution and quantification of the expression of PPARs and LXR $\alpha$ in humans: no alterations in adipose tissue of obese and NIDDM patients. Diabetes 48 1319-1327.

Auwerx J, Martin G, Guerre-Millo M \& Staels B 1996 Transcription, adipocyte differentiation, and obesity. Journal of Molecular Medicine 74 347-352.

Belluzi A, Brignola C, Campieri M, Pera A, Boschi S \& Miglioli M 1996 Effect of an enteric-coated fish-oil preparation on relapses in Crohn's disease. New England Journal of Medicine 334 1557-1560.

Braissant O, Foufelle F, Scotto C, Dauca M \& Wahli W 1995 Differential expression of peroxisome proliferator-activated receptors: tissue distribution of $\operatorname{PPAR} \alpha, \beta$ and $\gamma$ in the adult rat. Endocrinology 137 354-366.

Chomczynski P \& Sacchi N 1987 Single step method for RNA isolation by acid guanidinium-thiocyanate-phenol-chloroform extraction. Analytical Biochemistry 162 156-159.

De Vries CE \& Van Noorden C 1992 Effects of dietary fatty acid composition on tumor growth and metastasis. Anticancer Research 12 1513-1522.

Fajas L, Auboeuf D, Raspe E, Schoonjans K, Lefebvre AM, Saladin R, Najib J, Laville M, Fruchart JC, Deeb S, Vidal-Puig A, Flier J, Briggs MR, Staels B, Vidal H \& Auwerx J 1997 Organisation, promoter analysis and expression of the human PPAR $\gamma$ gene. Journal of Biological Chemistry 272 18779-18789.

Fajas L, Fruchart JC \& Auwerx J 1998 PPAR gamma3 mRNA: a distinct PPARgamma mRNA subtype transcribed from an independent promoter. FEBS Letters 438 55-60.

Forman BM, Tontonoz P, Chen J, Brun RP, Spiegelman BM \& Evans RM 1995 15-Deoxy- $\Delta^{12,14}$ prostaglandin $J_{2}$ is a ligand for the adipocyte determination factor PPAR $\gamma$. Cell 83 803-812. 
Giovanucci E, Egan KM, Hunter DJ, Stampfer MJ, Colditz GA, Willet WC \& Speiser FE 1995 Aspirin and the risk of colorectal cancer in women. New England Journal of Medicine 333 609-614.

Göttlicher M, Demoz A, Svensson D, Tollet P, Berge RK \& Gustafsson J-A 1993 Structural and metabolic requirements for activators of peroxisome proliferator-activated receptor. Biochemical Pharmacology 46 2177-2184.

Kliewer SA, Lenhard JM, Willson TM, Patel I, Morris DC \& Lehman JM 1995 A prostaglandin J2 metabolite binds peroxisome proliferatoractivated receptor $\gamma$ and promotes adipocyte differentiation. Cell $\mathbf{8 3}$ 813-819.

Laemmli UK 1970 Cleavage of structural proteins during the assembly of the head of bacteriophage T4. Nature 227 680-685.

Lauritsen K, Laursen LS, Bukhave K \& Rask-Madsen J 1986 Effects of topical 5-aminosalicylic acid and prednisolone on prostaglandin E2 and leukotriene B4 levels determined by equilibrium in vivo dialysis of rectum in relapsing ulcerative colitis. Gastroenterology $\mathbf{9 1}$ 837-844.

Lee TH \& Austen F 1985 Arachidonic acid metabolism by the 5-lipoxygenase pathway, and effects of alternative dietary fatty acids. Advances in Immunology 39 145-175.

McLean IW \& Nakane PK 1974 Periodate-lysine-paraformaldehyde fixative. A new fixation for immunoelectron microscopy. Journal of Histochemistry and Cytochemistry 22 1077-1083.

Mansen A, Guardiola-Diaz H, Rafter J, Branting C \& Gustafsson JA 1996 Expression of the peroxisome proliferator-activated receptor (PPAR) in the mouse colonic mucosa. Biochemical and Biophysical Research Communications 222 844-851.

Masiakowski P, Breathnach R, Bloch J, Gannon F, Krust A \& Chambon P 1982 Cloning of cDNA sequences of hormoneregulated genes from MCF-7 human breast cancer cell line. Nucleic Acids Research 10 7895-7903.

Pinto M, Robine-Leon S, Appay MD, Triadou N, Dussaulx E, Lacroix B, Simon-Assman P, Haffen K, Fogh J \& Zweibaum A 1983 Enterocyte-like differentiation and polarisation of the human colon carcinoma cell line Caco-2 in culture. Biology of the Cell $\mathbf{4 7}$ 323-330.

Potter JD 1992 Reconciling the epidemiology, physiology, and molecular biology of colon cancer. Journal of the American Medicine Association 268 1573-1577.

Potter JD \& McMichael AJ 1986 Diet and cancer of the colon and rectum: a case-control study. Journal of the National Cancer Institute 76 557-569.

Saladin R, De Vos P, Guerre-Millo M, Leturque A, Girard J, Staels B \& Auwerx J 1995 Transient increase in obese gene expression after food intake and insulin administration. Nature 377 527-529.
Schoonjans K, Martin G, Staels B \& Auwerx J 1997 Peroxisome proliferator-activated receptors, orphans with ligands and functions. Current Opinion in Lipidology 8 159-166.

Sharon P \& Stenson WF 1984 Enhanced synthesis of leukotriene B4 by colonic mucosa in inflammatory bowel disease. Gastroenterology 86 453-460.

Shu S, Ju G \& Fan L 1988 The glucose oxidase-DAB-nickel method in peroxidase histochemistry of the nervous system. Neuroscience Letters 85 169-171.

Spiegelman BM \& Flier JS 1996 Adipogenesis and obesity: rounding out the big picture. Cell 87 377-389.

Stenson WF, Cort D, Rodgers J, Burakoff R, DeSchryver-Kecskemet K, Gramlich TL \& Beeken W 1992 Dietary supplementation with fish oil in ulcerative colitis. Annals of Internal Medicine 116 609-614.

Thun MJ, Namboodiri MM \& Heath CW 1991 Aspirin use and reduced risk of fatal colon cancer. New England Journal of Medicine 325 1593-1596.

Tontonoz P, Hu E \& Spiegelman BM 1994 Stimulation of adipogenesis in fibroblasts by PPAR $\gamma 2$, a lipid-activated transcription factor. Cell 79 1147-1156.

Towbin H, Staehelin T \& Gordon J 1979 Electrophoretic transfer of proteins from polyacrylamide gels to nitrocellulose sheets: procedure and some applications. Proceedings of the National Academy of Sciences of the USA 76 4350-4354.

Wasan HS, Novelli M, Bee J \& Bodmer WF 1997 Dietary fat influences on polyp phenotype in multiple intestinal neoplasia mice. Proceedings of the National Academy of Sciences of the USA 94 3308-3313.

Wingo PA, Tong T \& Bolden S 1995 Cancer statistics. Cancer Journal for Clinicians 45 8-30.

Zhang B, Graziano MP, Doebber TW, Leibowitz MD, WhiteCarrington S, Szalkowski DM, Hey PT, Wu M, Cullinan CA, Bailey P, Lollmann B, Frederich R, Flier JS, Strader CD \& Smith RG 1996 Down-regulation of the expression of the obese gene by antidiabetic thiazolidinedione in Zucker diabetic fatty rats and $d b / d b$ mice. Journal of Biological Chemistry 271 9455-9459.

Zweibaum A, Pinto M, Chevalier G, Dussaulx E, Triadou N, Lacroix B, Haffen K, Brub JL \& Rousset M 1985 Enterocytic differentiation of a subpopulation of the human colon tumor cell line HT-29 selected for growth in sugar-free medium and its inhibition by glucose. Journal of Cellular Physiology 122 21-29.

Received 16 December 1998

Accepted 9 April 1999 